\title{
FLUID TRANSPORT OF SULFUR AND METALS BETWEEN SULFIDE MELT AND BASALTIC MELT
}

\author{
DON R. BAKER ${ }^{\S}$ \\ Department of Earth and Planetary Sciences, McGill University, 3450 University Street, Montreal, Quebec H3A 2A7, Canada
}

SARAH-JANE BARNES

Sciences de la Terre, Université du Québec à Chicoutimi, Chicoutimi, Quebec G7H 2B1, Canada

GAIL SIMON AND FREDERIC BERNIER

Department of Earth and Planetary Sciences, McGill University, 3450 University Street, Montreal, Quebec H3A 2A7, Canada

\begin{abstract}
Experiments were performed at $1.0 \mathrm{GPa}$ and temperatures between 1225 and $1450^{\circ} \mathrm{C}$ to demonstrate the transport of sulfur and metals $\mathrm{Cu}, \mathrm{Ni}$ and $\mathrm{Pt}$ into a basaltic melt via a sulfurous fluid phase. Experiments were performed inside graphite-lined $\mathrm{Pt}$ capsules by converting a mixture of $\mathrm{FeS}_{2}+\mathrm{NiS}_{2}+\mathrm{CuS}$ into sulfide melt + a sulfurous fluid, which was kept separate from a basaltic melt inside the same Pt capsule by a gas-permeable graphite membrane. The sulfurous fluid is rapidly transported, and the basaltic melt achieves $S$ concentrations similar to saturation values (within $2 \sigma$ ) in times less than 1 hour, even though the two melts are not in physical contact. The sulfurous fluid is shown to transport significant quantities of $\mathrm{Cu}, \mathrm{Ni}$ and $\mathrm{Pt}$ in 1 hour. Gold is transported out of the melt. A process similar to the one experimentally modeled could occur in nature as magmatic systems heat country rocks to temperatures at which pyrite converts to pyrrhotite + a sulfurous fluid, potentially containing significant quantities of ore metals. The volume change of this reaction could crack the country rocks and allow the fluid to enter the magma chamber. These fluids could then saturate the melt, causing the formation of immiscible sulfide droplets enriched in base and precious metals, eventually forming either the progenitor of an ore deposit or the ore deposit itself.
\end{abstract}

Keywords: ore deposits, sulfur, metal transport, copper, nickel, platinum, basalt, experimental petrology.

\section{SOMMAIRE}

Nous avons étudié le transfert du soufre et des métaux $\mathrm{Cu}$, Ni et Pt, incorporés dans un bain fondu basaltique, par le biais d'une phase volatile sulfureuse à une pression de $1.0 \mathrm{GPa}$ et des températures entre 1225 et $1450^{\circ} \mathrm{C}$. Ces expériences, effectuées dans un récipient de platine avec gaine de graphite, ont donné un liquide sulfuré et une phase volatile sulfureuse à partir d'un mélange de $\mathrm{FeS}_{2}+\mathrm{NiS}_{2}+\mathrm{CuS}$, maintenu séparé du liquide basaltique à l'intérieur de la même capsule en platine au moyen d'une membrane de graphite perméable au gaz. Le fluide sulfuré est rapidement transporté, et le liquide basaltique atteint une saturation en soufre, les teneurs étant semblables à celles prévues dans un cas de saturation (à $2 \sigma$ près) en moins d'une heure, malgré le fait que les deux liquides n'étaient pas en contact. Le fluide sulfuré peut transporter des quantités importantes de $\mathrm{Cu}, \mathrm{Ni}$ et $\mathrm{Pt}$ en une heure. En revanche, l'or a été extrait du liquide. Un processus semblable à celui que nous avons simulé par expériences pourrait être important dans les cas où un système magmatique réchauffe les roches encaissantes suffisamment pour déstabiliser la pyrite et produite la pyrrhotite + une phase fluide sulfurée qui pourrait contenir des quantités importantes de métaux d'intérêt économique. Le changement de volume associé à cette réaction de dégazage pourrait craquer les roches encaissantes et ainsi donner à la phase fluide libre accès à la chambre magmatique. Le magma pourrait par la suite devenir saturé en soufre, ce qui mènerait à la formation de goutelettes de liquide sulfuré immiscibles enrichies en métaux de base et métaux précieux. Ce processus pourrait former un précurseur à un gîte minéral, ou bien le gisement lui-même.

(Traduit par la Rédaction)

Mots-clés: gîte minéral, soufre, transport de métaux, cuivre, nickel, platine, basalte, pétrologie expérimentale.

§ E-mail address: donb@eps.mcgill.ca 


\section{INTRODUCTION}

Numerous studies of massive sulfide deposits associated with mafic magmas have demonstrated that the isotopic signatures of sulfur indicate a crustal source because $\delta^{34} \mathrm{~S}$ values deviate significantly from the mantle signature of $\sim 0 \%$ o (Ripley 1999, and references therein). Many authors have attributed the mechanism of saturation of the mafic magma in a sulfide liquid to assimilation of crustal country-rocks; the source of metals for the deposit is presumed to be the mantle (see review by Lesher \& Campbell 1993). However, for some metals, the source may well be the same as that of the sulfur, i.e., the crust (Barnes et al. 1997, Thériault et al. 1997). Incorporation of sulfur from the crust into mafic magmas is generally presumed to occur by bulk assimilation of country rocks. However, a fluid-transport process in which a sulfurous fluid is released from country rocks surrounding the magma chamber and its feeders due to the prograde metamorphic reaction

$$
\mathrm{FeS}_{2} \Leftrightarrow \mathrm{FeS}+1 / 2 \mathrm{~S}_{2}
$$

could potentially allow the fluid to interact with a large volume of country rocks between its site of origin in the metamorphic aureole and the magma chamber (Fig. 1). This larger volume of interaction might result in substantial removal of metals from country-rock minerals by the sulfurous fluid, incorporation into the magma, followed by later deposition in the magma chamber as the melt became saturated in sulfides.

In this paper, we present the results of a reconnaissance experimental investigation of this proposed fluidtransport mechanism for sulfur and ore metals. As will be shown below, the breakdown of pyrite can produce a fluid which in the experiments rapidly transports sulfur

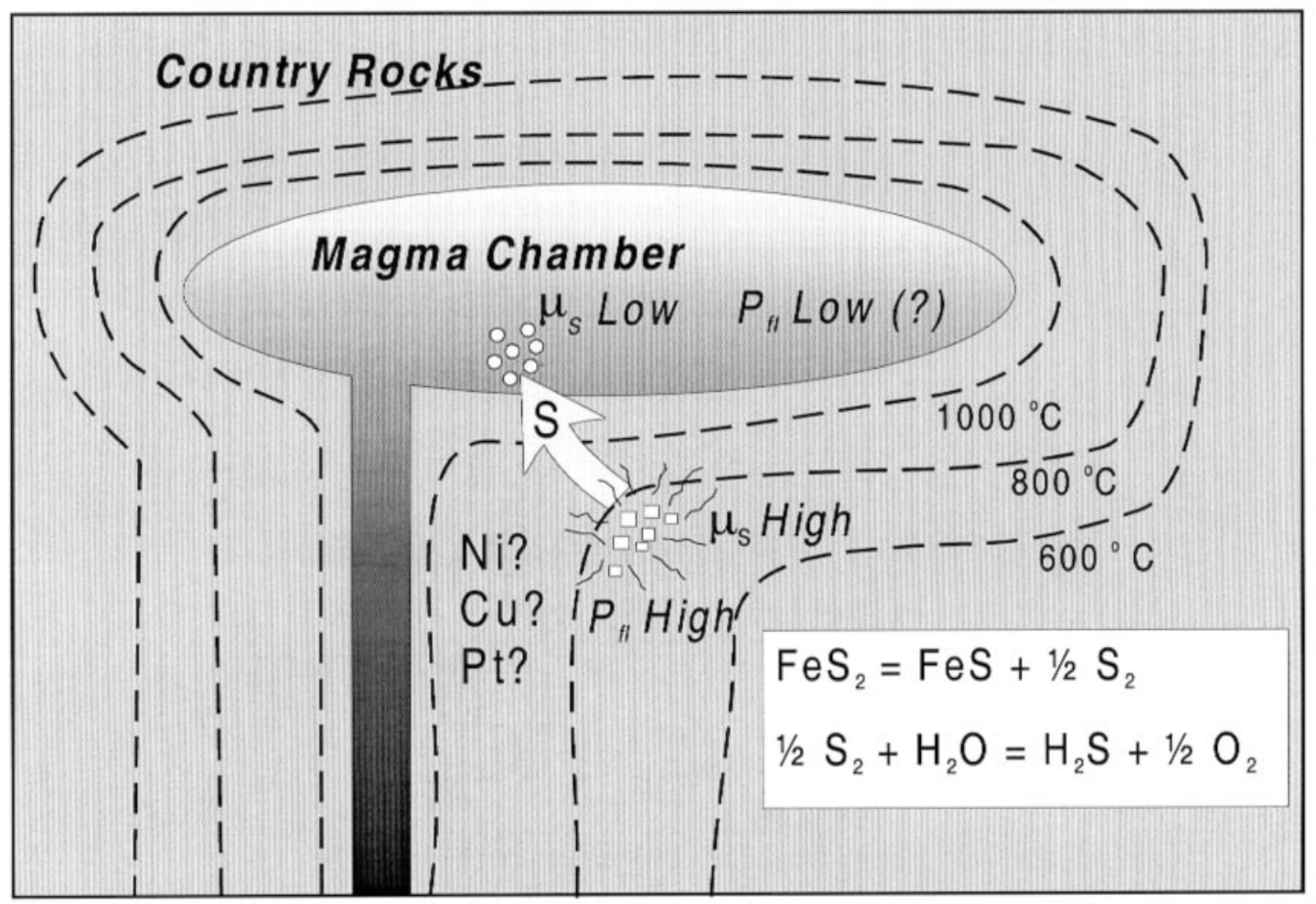

FIG. 1. Conceptual model for fluid transport of sulfur from country rocks into magma, after Barnes et al. (1997). The hypothesis is that the intrusion of magma raises country-rock temperatures above the stability of pyrite (white squares), which breaks down to pyrrhotite $+\mathrm{S}_{2}$. This sulfurous fluid reacts with water present to produce a sulfurous fluid dominated by $\mathrm{H}_{2} \mathrm{~S}$. In the region of pyrite breakdown, the chemical potential of sulfur, $\mu_{S}$, and the pressure of the fluid phase, $\mathrm{P}_{\mathrm{fl}}$, are greater than in the magma. The high fluid pressure cracks the rocks, and the combination of high fluid pressure and high chemical potential drives $\mathrm{S}$ into the magma, possibly carrying $\mathrm{Ni}, \mathrm{Cu}$, and $\mathrm{Pt}$ extracted from the country rocks. The magma becomes saturated with $\mathrm{S}$, and immiscible sulfide droplets form (white circles), which are potentially enriched in base and precious metals. 
into a basaltic melt. This fluid is also shown to be an efficient transport agent of $\mathrm{Cu}, \mathrm{Ni}, \mathrm{Pt}$ and possibly $\mathrm{Au}$.

\section{Conceptual Background}

Reactions involving the breakdown of pyrite will be more complex than equation (1); at oxygen fugacities near the fayalite - magnetite - quartz (FMQ) buffer, the liberated sulfur will probably react with any available water:

$$
1 / 2 \mathrm{~S}_{2}+\mathrm{H}_{2} \mathrm{O} \Leftrightarrow \mathrm{H}_{2} \mathrm{~S}+1 / 2 \mathrm{O}_{2}
$$

The volume change, $\Delta \mathrm{V}$, for the combined reactions 1 and 2 was determined with volumes of solids from the tabulation of Robie et al. (1979) at 298.15 K, 0.1 MPa, and volumes of fluid calculated at temperature and pressure with the modified Redlich-Kwong equation of state (see program listing in Holloway \& Blank 1994) using the parameters for $\mathrm{H}_{2} \mathrm{~S}$ and $\mathrm{H}_{2} \mathrm{O}$ from Ferry \& Baumgartner (1987) and Holloway \& Blank (1994), respectively. The volume of oxygen in the reaction was presumed to be negligible. The calculated $\Delta \mathrm{V}$ for the combined reactions at $800^{\circ} \mathrm{C}, 200 \mathrm{MPa}$ is $5.5 \mathrm{~cm}^{3}$ $\mathrm{mol}^{-1}$. This magnitude of $\Delta \mathrm{V}$ is similar to that deemed
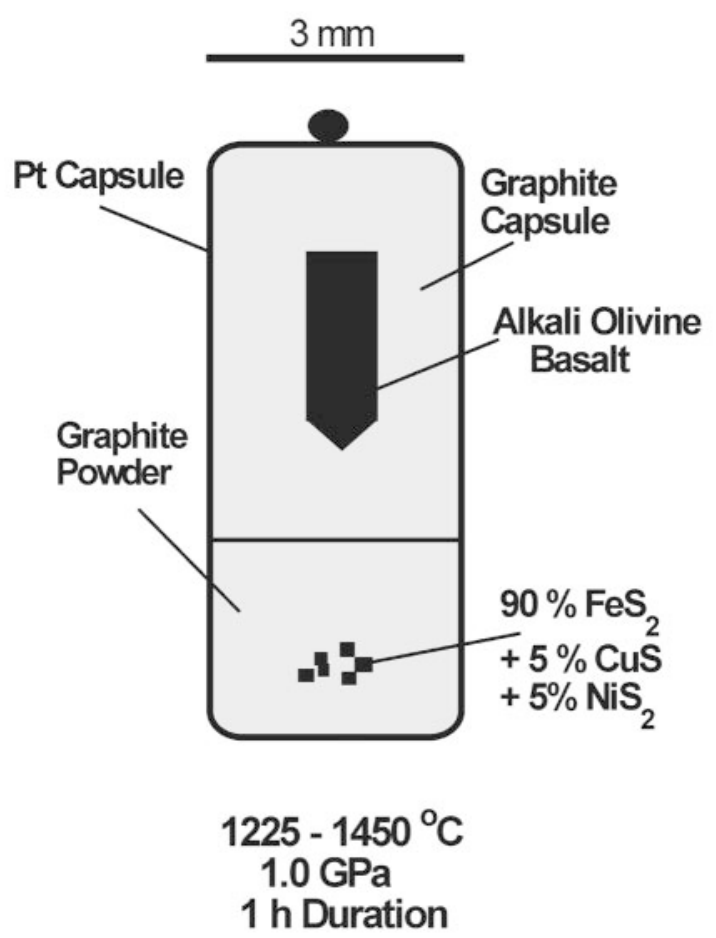

FIG. 2. Experimental capsule designed to produce a sulfurous fluid by the breakdown of pyrite to a sulfide melt + sulfurous fluid, and to maintain the sulfide melt separated from the basaltic melt while allowing the transport of the fluid into the basaltic melt. sufficient to crack the country rocks (Clemens \& Mawer 1992), potentially creating pathways for the transport of fluids toward the magma chamber. The driving forces for migration of the sulfurous fluid would be both the pressure gradient formed by the pyrite breakdown reaction and the chemical potential difference between the $\mathrm{S}$-rich and S-poor regions in the country rocks and the magma chamber (Fig. 1). Although the transport of fluid against a thermal gradient is contrary to the accepted wisdom of many geologists, numerical simulations of contact metamorphism demonstrate that fluid flow during contact metamorphism can be in the direction of higher temperatures under some conditions (e.g., Ferry 1991). The transport of sulfur from the pyrite breakdown reaction to the magma chamber would have to be rapid because given sufficient time, the fluid phase is expected to react with iron-bearing silicates to form pyrrhotite and remove the fluid from the system.

\section{ExPERImental and Analytical Techniques}

Experiments in this study were designed to create a sulfurous fluid by the breakdown of pyrite into an FeS melt + a sulfurous fluid and to maintain that melt separate from a basaltic melt by a gas-permeable membrane (Fig. 2). Experimental capsules consisted of an outer Pt capsule $3 \mathrm{~mm}$ in diameter. Into this capsule were sequentially placed: a $1 \mathrm{mg}$ layer of graphite powder, a $3 \mathrm{mg}$ mixture of reagent-grade sulfides consisting of 90 wt. $\% \mathrm{FeS}_{2}+5 \% \mathrm{NiS}_{2}+5 \% \mathrm{CuS}$, another $1 \mathrm{mg}$ layer of graphite powder followed by a graphite inner capsule, which contained $3 \mathrm{mg}$ of an alkali olivine basalt, P-1 (Table 1), graciously donated by G. Mahood (Mahood \& Baker 1987). After loading, all Pt capsules were welded closed in a water bath to avoid volatile loss. The oxygen fugacity in these experiments is below the wüstite-magnetite buffer (Dalpé \& Baker 2000), and thus the speciation of sulfur in the silicate melt should be dominated by $\mathrm{S}_{2}^{-}$(Carroll \& Webster 1994), and in the presence of hydrogen (which is omnipresent in experimental assemblies), the dominant species in the fluid is $\mathrm{H}_{2} \mathrm{~S}$ ( $c f$. Ferry \& Baumgartner 1987, Ballhaus et al. 1994). During the experiments, the sulfide mixture broke down to produce a $(\mathrm{Fe}, \mathrm{Ni}, \mathrm{Cu})_{1-x} \mathrm{~S}$ melt and a sulfurous fluid. This fluid reacts with the hydrogen present

T.ABLE 1, COMPOȘITION OF ALKALI OLTVTEE BASALT F-1

\begin{tabular}{|c|c|c|c|}
\hline $5 O_{2} w t \%$ & 47.6 & $\mathrm{Ka}_{1} \mathrm{O}$ wt. & 3.30 \\
\hline $\mathrm{TiO}_{2}$ & 2.67 & $\mathrm{~K}_{\mathrm{O}} \mathrm{O}$ & 0.96 \\
\hline $\mathrm{Al}_{2} \mathrm{O}_{3}$ & 15.8 & $\mathrm{P}_{2} \mathrm{O}_{3}$ & 0.60 \\
\hline $\mathrm{FeO}^{*}$ & 10.7 & रi pprn & 235 \\
\hline Mino & 0.18 & Cu pott: & 72,5 \\
\hline MụO & 5.61 & & \\
\hline $\mathrm{CaO}$ & 11.4 & total & 99.82 \\
\hline
\end{tabular}

Composition wes establiahed by X-ray-fluorescence analysis; results are from $\mathrm{Mah}$ oof a Baker (1987). The enncentuation of $\mathrm{N} \sqrt{3}$ and $\mathrm{Cu}$ was establisher by atomic absorption at MoGill Unirersity. 
in the capsule to create a $\mathrm{H}_{2} \mathrm{~S}$-dominated fluid that can be transported into the silicate melt. Experiments designed to evaluate breakdown reactions involving the formation of crystalline sulfides rather than sulfide melt were not feasible because sulfides in the system $\mathrm{Fe}-\mathrm{Ni}-$ $\mathrm{Cu}-\mathrm{S}$ are molten at the liquidus temperature of the anhydrous basalt used in this study, $\sim 1250^{\circ} \mathrm{C}$.

All experiments were performed in a piston-cylinder apparatus using $\mathrm{NaCl}$ - pyrex - crushable alumina assemblies. Recent calibrations of these assemblies using the melting curve of $\mathrm{NaCl}$ (Bohlen 1984) demonstrate that no pressure correction is necessary. Experiments were done at $1.0 \pm 0.025 \mathrm{GPa}$ and temperatures between 1225 and $1450^{\circ} \mathrm{C}$ (Table 2). Most experiments were done at superliquidus conditions in order to assure large volumes of glass for electron microprobe and laser-ablation microprobe - ICP-MS (LAM-ICP-MS) analysis. The experimental pressure exceeds that at which the natural process probably occurs, but was used to ensure the stability of the experi- ments. Experimental durations varied from $0.25 \mathrm{~h}$ to 6 h. Experiments were quenched at rates of approximately $2000^{\circ} \mathrm{C} / \mathrm{min}$.

After each experiment, entire capsules were mounted in epoxy and ground open to reveal the quenched basaltic glass in the center of the inner graphite capsule. Samples were then polished for electron microprobe and LAM-ICP-MS analysis. Glasses were analyzed for major and minor elements with a JEOL 8900 electron microprobe. We used a natural basaltic glass from the Juan de Fuca fracture zone as the standard when analyzing glass for the major elements $\mathrm{Si}, \mathrm{Ti}, \mathrm{Al}, \mathrm{Fe}, \mathrm{Mg}$, $\mathrm{Ca}, \mathrm{Na}$, and $\mathrm{K}$, and also for $\mathrm{S}$. Apatite was used as a standard for $\mathrm{P}$, and spessartine for Mn. Where sulfides were analyzed, $\mathrm{FeS}_{2}$ was used as the standard for both $\mathrm{Fe}$ and $\mathrm{S}, \mathrm{CuO}$ for $\mathrm{Cu}, \mathrm{NiO}$ for $\mathrm{Ni}$ and $\mathrm{O}$, and pure metal for Pt. A $15 \mathrm{kV}$ accelerating voltage and $10 \mathrm{nA}$ beam were used for analyses of glass, and a $30 \mathrm{nA}$ beam was used for analyses of sulfide. All elements, except for $\mathrm{S}$ in the glass, were counted for $20 \mathrm{~s}$ on the peak and $10 \mathrm{~s}$

TABLE 2. COMPOSITIONS OF SILICATE MEI.TS PRODUCED IN EXPERTMENTS

\begin{tabular}{|c|c|c|c|c|c|c|c|c|c|c|c|c|}
\hline Run & GS-13] & GS-14 & GS-1 & $\operatorname{GS}-2$ & GS-3 & GS-5 & GS.7 & 3TF-G & STE-7 & GS-15 & GS-17 & GS-19 \\
\hline Temp $\left({ }^{\circ} \mathrm{C}\right)$ & 1450 & 1450 & 1400 & 1400 & 1400 & 1400 & 1300 & 1225 & 1225 & 1300 & 1450 & $1450 / 300^{4}$ \\
\hline Time (h) & 1 & 0.25 & 6 & 6 & 6 & J & 1 & 5 & 5 & 1 & 1 & $1 / \sqrt{1}$ \\
\hline Pressure (GP & Pa) 1 & 1 & I & t & 1 & 1 & 1 & 1 & 1 & ] & 1 & 1 \\
\hline $\begin{array}{l}\text { Starting } \\
\text { materials }\end{array}$ & $\begin{array}{c}\text { P-I + } \\
\text { sulfides }\end{array}$ & $\begin{array}{c}\text { P-1 + } \\
\text { sialfides }\end{array}$ & $P-1$ & $\begin{array}{l}\text { P-1 + } \\
\text { sultides }\end{array}$ & $\begin{array}{c}\text { P-1 + } \\
\text { sulfides }\end{array}$ & $\begin{array}{l}\text { P-j+ } \\
\text { sulfides }\end{array}$ & $\begin{array}{l}\text { P-1 + } \\
\text { tulfides }\end{array}$ & P-1 & $\begin{array}{c}\text { P-1 + } \\
\text { prrite }\end{array}$ & $\begin{array}{c}\mathrm{P}-\mathbf{l}+ \\
\mathbf{P o}^{3}\end{array}$ & $\begin{array}{c}\mathrm{P}-1+ \\
\mathrm{Po}^{3}\end{array}$ & $\begin{array}{c}\mathrm{P}-\mathrm{i}+ \\
\mathrm{Po}^{3}\end{array}$ \\
\hline $\begin{array}{l}\text { Rug } \\
\text { profugts }\end{array}$ & $\begin{array}{l}\text { Melt + } \\
\text { S-Itelt }\end{array}$ & Welt & Melt & $\begin{array}{l}\text { Melt + } \\
\text { S-Mielt } \\
+ \text { alloy }\end{array}$ & $\begin{array}{l}\text { Mfelt + } \\
\text { S-Malt } \\
+ \text { aloy }\end{array}$ & Melt & Melt & $\begin{array}{l}\text { Melt + } \\
\text { Cpx + } \\
\text { Pl }\end{array}$ & $\begin{array}{c}\text { Melt + } \\
\text { S-Melt + } \\
\text { Cpx + Pd }\end{array}$ & $\begin{array}{l}\text { Melt + } \\
\text { S-Whett }\end{array}$ & $\begin{array}{l}\text { Mel: + } \\
\text { S-Melt }\end{array}$ & $\begin{array}{l}\text { Melt + } \\
\text { S-3welt }\end{array}$ \\
\hline \# Analyses: & 6 & 10 & 12 & 10 & 9 & 10 & 8 & 10 & 11 & 14 & 17 & 10 \\
\hline
\end{tabular}

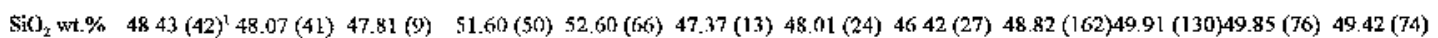

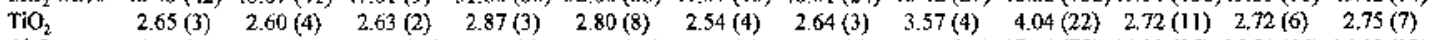

$\mathrm{Al}_{2} \mathrm{O}_{7} \quad 16.00(18) 15.84(26) 15.42(2 \mathrm{l}) 17.00(7) \quad 17.35$ (33) $15.76(6) \quad 15.93(9) \quad 15.65(15) 17.54(75) 16.32(35) 16.51$ (14) $16.13(1 \mathrm{~g})$

$\left.\left.\mathrm{FeO}^{*} \quad 7.57(32) 10.70(66)\right] 6.85(12) \quad\right] .42(8) \quad 0.10(3) \quad 1030(13) \quad 9.20(15) \quad 11.53(10) \quad 5.39(172) 6.91(1.62) 5.42(55) \quad 5.87(43)$

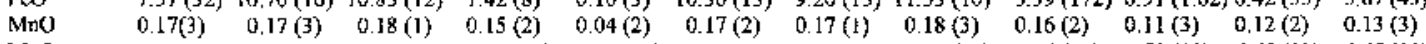

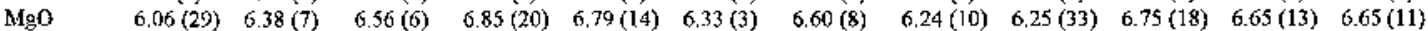

$\mathrm{CaO} \quad 11.19(38) 11.22(9) \quad 11.38(10) 12.58(29) 12.86(20) 11.12(5) \quad 11.15(15) 10.37(10) 10.34(34) 11.84(15) 11.70(13) 11.59(12)$

$\mathrm{Na}_{2} \mathrm{O} \quad 2.45(33) \quad 3.02(62) \quad 3.22(14) \quad 3.43(12) \quad 3.25(84) \quad 2.97(5) \quad 3.16(5) \quad 3.66(5) \quad 3.57(160) 3.12(21) \quad 3.21(11) \quad 2.59(37)$

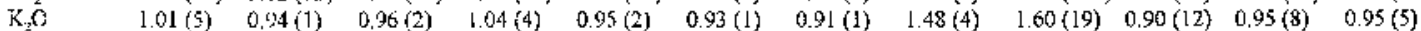

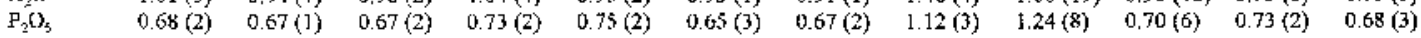

$\mathrm{S}^{2} \quad 0.280(36) 0.113(4) \quad 0.0070(8) 0.177(6) \quad 0.124(8) \quad 0.182(19) 0.096(15) 0.0116(12) 0.0525(97) 0.149(9) \quad 0.205(25) 0.146(15)$

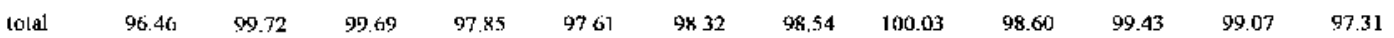

LAM-ICP-MS data

$\begin{array}{lcccc}\text { \# Analyges } & 3 & 4 & 9 & 9 \\ \text { Ni (ppm) } & & & & \\ \text { Cu (ppm) } & 0.4(1) & 1.5(5) & 2.2(10) & 7.6(26) \\ \text { Pt (ppm) } & 1.0(3) & 5.5(10) & 4.7(20) & 5.2(21) \\ \text { Au (ppm) } & 0.05(3) & 3.5(30) & 0.05(5) & 0.03(2) \\ & 0.2(05) & 0.04(2) & 0.08(4) & 0.05(4)\end{array}$

\footnotetext{
1 Average result of multiple analyses is followed by one standard deviation in terms of least units cited. Concentrations are in wt\%

${ }^{2}$ Pure pytite, not the sulfide mix, was used for this experiment.

${ }^{3}$ Powdered natural pythotite piaced in direct contact with the basallic starting tuatertal.

" Reversal experiment first melted at $1450^{\prime 2} \mathrm{C}, 1.0 \mathrm{GPa}$ for $1 \mathrm{~h}$ followed by cooling $101300^{\circ} \mathrm{C}, 1.0 \mathrm{GPa}$, where the experinent was maintained for an additimal bour before quenching.
} 
on each background. For the measurement of the S concentration in the glass, the counting time was $300 \mathrm{~s}$ on the peak and $150 \mathrm{~s}$ on each background. The minimum detection limit for $\mathrm{S}$ is $50 \mathrm{ppm}$, for $\mathrm{Cu}, 180 \mathrm{ppm}$, and for Ni, 75 ppm. Reconnaissance laser-ablation ICP-MS analysis of four products of experiments was performed with the Fisons VG PQII+ at the Université de Montréal for the elements $\mathrm{Au}, \mathrm{Cu}, \mathrm{Ni}$, and Pt. Analytical procedures are similar to those described in Dalpé et al. (1995) and Hoosain (1999). A 1064 nm Nd:YAG laser operating at a blank voltage of $610 \mathrm{~V}$ and frequency of $4 \mathrm{~Hz}$ in the Q-switched mode was used for the analysis. Calibration was performed using NIST 610 glass as the standard. Unfortunately, previous analyses of basaltic glasses using the NIST 610 standard have demonstrated substantial differences between Ni concentrations measured by LAM-ICP-MS and XRF or other techniques. We suspect similar discrepancies for $\mathrm{Cu}$. Because of these differences, all concentrations of $\mathrm{Ni}$ and $\mathrm{Cu}$ measured by LAM-ICP-MS need to be multiplied by a factors of 639 and 65.4 , respectively, to bring the measured concentrations of these elements in $\mathrm{P}-1$ glass produced in control experiment GS-1 (Table 2) to the same levels as in Table 1. No standards were available for Pt, such that measurements are reported relative to an assumed concentration of 1 ppm in NIST 610 glass. Because of these uncertainties, we concentrate on relative abundances referenced to those in the control experiment glass, GS-1, rather than on absolute abundances.

\section{RESUlts}

\section{Sulfur concentrations in mafic melts}

Two control experiments (GS-1, STE-6) were performed using graphite-encapsulated basalt inside Pt cap-

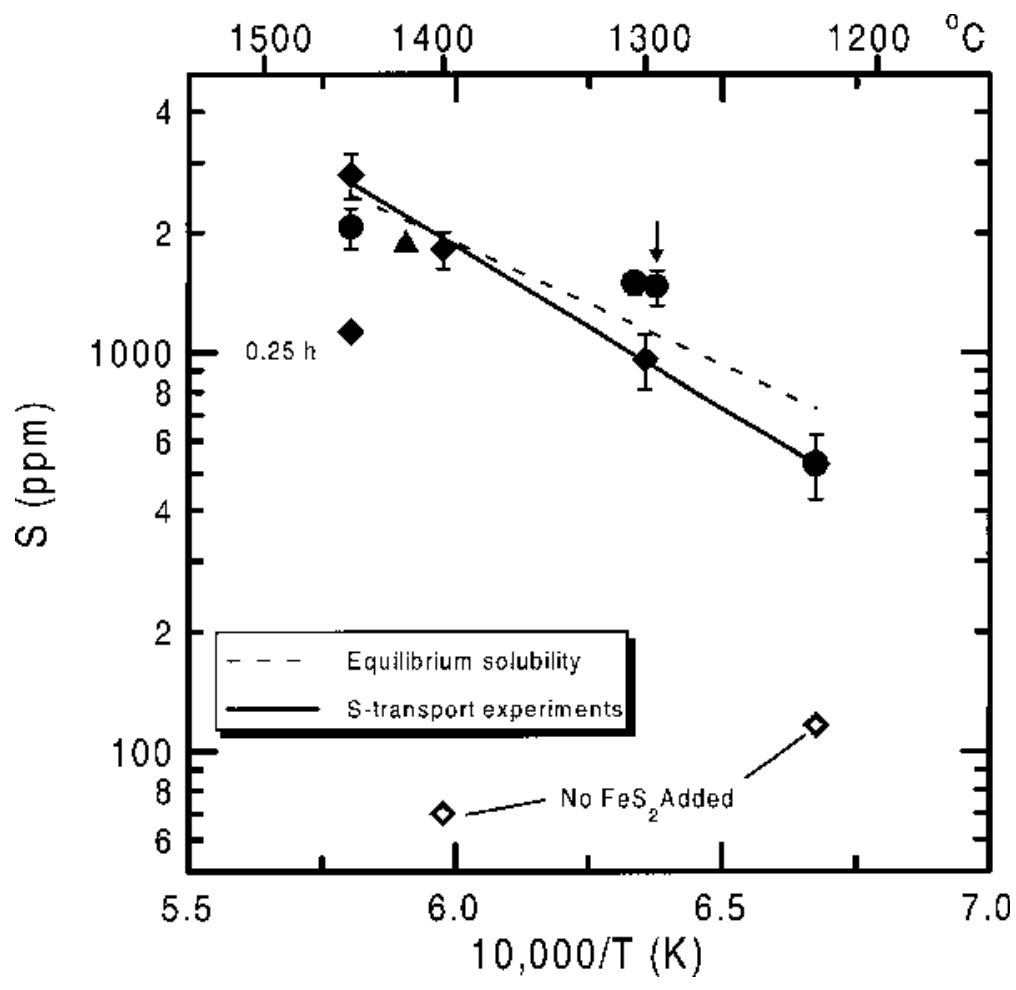

FIG. 3. Sulfur concentrations in basaltic melt from sulfur-transfer experiments (diamonds), and equilibrium experiments (circles), where pyrrhotite was placed in contact with melt. Equilibrium experiments at $1300^{\circ} \mathrm{C}$ are displaced horizontally for clarity; the downward-pointing arrow indicates the reversal experiment (GS-18) that was first equilibrated at $1450^{\circ} \mathrm{C}, 1.0 \mathrm{GPa}$, then cooled to $1300^{\circ} \mathrm{C}, 1.0 \mathrm{GPa}$. The equilibrium experiment from Wendlandt (1982) (triangle) was performed using the same technique and a similar composition of melt as equilibrium experiments in this study, but at a pressure of $1.25 \mathrm{GPa}$. The open diamonds are control experiments performed without added sulfides using the same capsules as the sulfur-transfer experiments. Error bars are one standard deviation about the mean based upon multiple analyses. Where not shown, error bars are smaller than the symbols. 
sules that did not contain any sulfides (Table 2, Fig. 3). Melts produced in both cases contain less than $120 \mathrm{ppm}$ S. Owing to the crystallization of clinopyroxene and plagioclase in STE-6 at $1225^{\circ} \mathrm{C}$, the concentration of S in this residual melt is approximately 1.5 times greater than in GS- 1 at $1400^{\circ} \mathrm{C}$, which is at superliquidus conditions.

Initial experiments of 5 or $6 \mathrm{~h}$ duration demonstrated increased concentrations of sulfur in the melt and formation of sulfide and metal in the basaltic melt (GS-2 and -3 , STE-7). Although providing important evidence of $\mathrm{S}$ transport into the basaltic melt, these relatively long-duration experiments suffered extensive loss of iron to the sulfides and metals (Table 2), and thus the melt compositions are no longer similar to naturally occurring basaltic compositions. Therefore, most of the reported experiments are of $1 \mathrm{~h}$ duration; however, even some of these experiments resulted in the formation of sulfide melts (GS-13), and despite our best efforts, many experiments suffered some iron loss from the silicate melt.

Anhydrous sulfur-transfer experiments of $1 \mathrm{~h}$ duration demonstrate increasing $\mathrm{S}$ concentrations with increasing temperature. Sulfur transport in this experimental system is rapid; using sulfur abundances measured in 0.25 and $1 \mathrm{~h}$ duration experiments at $1450^{\circ} \mathrm{C}$, the rate of sulfur transport in these experiments can be estimated at $5 \times 10^{-6} \mathrm{~g} \mathrm{~h}^{-1}$. The presence of quenched iron sulfide melts inside the basaltic melt in the $1 \mathrm{~h}$ experiments at $1450^{\circ} \mathrm{C}(\mathrm{GS}-13)$ supports the interpretation that melts achieved sulfide saturation. In these experiments, the sulfur concentration was found to be homogeneous and unzoned from the capsule wall to the interior. In none of the experiments were any vesicles or fluid inclusions detected.

Equilibrium experiments were performed with $1 \mathrm{mg}$ of powdered natural pyrrhotite placed in contact with the basaltic powder inside the graphite capsule (GS-15, -17 and -18 , Tables 2,3 ) at 1300 and $1450^{\circ} \mathrm{C}$ for comparison. The results of these experiments, combined with a sulfur-solubility measurement made on the compositionally similar Goose Island basalt at $1.25 \mathrm{GPa}$ (Wendlandt 1982) and the 6-h-long duration sulfurtransport experiment STE-7 (Table 2), which contained a trace of sulfide melt in contact with the residual basaltic melt, were used to constrain the equilibrium solubility of $\mathrm{S}$ in the mafic melt at the experimental conditions.

Comparison of the equilibrium solubilities measured when FeS was in direct contact with melt and our experiments, in which the graphite capsule isolated the basalt from the original source of sulfur, demonstrate excellent agreement (Table 3, Fig. 3), typically within one standard deviation and always within two of the equilibrium $\mathrm{S}$ solubility.

Analytical totals of glass analyses in the sulfur-transfer experiments are low (Table 2). Such low totals were not observed in either control experiment. The low totals are not due to analytical error, but rather to $\mathrm{H}_{2} \mathrm{O}$ created in the melt by the reaction of the $\mathrm{H}_{2} \mathrm{~S}$-bearing fluid with the basaltic melt:

$$
\mathrm{H}_{2} \mathrm{~S}^{\text {fluid }}+\mathrm{O}^{\text {melt }}=\mathrm{S}^{\text {melt }}+\mathrm{H}_{2} \mathrm{O}^{\text {melt }} \text {. }
$$

Thus for each gram of $\mathrm{H}_{2} \mathrm{~S}$ that interacts with oxygen in the silicate melt, $0.53 \mathrm{~g}$ of $\mathrm{H}_{2} \mathrm{O}$ should be produced by Reaction 3. In the absence of sulfide melts in contact with the basaltic melt, the amount of $\mathrm{H}_{2} \mathrm{O}$ added to the melt by Reaction 3 can be calculated from the $\mathrm{S}$ concentration in the melt. Although $\mathrm{H}_{2} \mathrm{O}$ concentrations were not measured in the glasses, the low analytical totals of experiments are broadly consistent with the expected amount of $\mathrm{H}_{2} \mathrm{O}$ addition based upon $\mathrm{S}$ concentrations and Reaction 3. In addition, longer-duration experiments resulted in the production of volumetrically more sulfide melts inside the basaltic melt and lower totals in the latter (Table 2), as predicted by Reaction 3.

\section{Trace-element concentrations in melts}

Four experiments were chosen for LAM-ICP-MS analysis to investigate the transport of trace elements by the sulfurous fluid. Comparison of the levels of $\mathrm{Au}$, $\mathrm{Cu}, \mathrm{Ni}$, and Pt measured in the melt demonstrates measurable differences in concentration with respect to the control experiment, GS-1 (Fig. 4). However, the concentrations of $\mathrm{Au}$ and $\mathrm{Pt}$ are so low that the measured values may be significantly affected by heterogeneities present in the starting rock powder. Only silicate glass was analyzed for trace elements because of possible contamination of the ICP-MS system by the ablation of sulfides.

The sulfurous fluid transports gold naturally present in the starting material out of the silicate melt. The concentration of $\mathrm{Au}$ in GS-2 at $1400^{\circ} \mathrm{C}$ is only $20 \%$ of the concentration in the control experiment. Gold depletion is less important in GS-5 at $1400^{\circ} \mathrm{C}$, which contains approximately $38 \%$ of the Au concentration in the control experiment, and in GS-7 at $1300^{\circ} \mathrm{C}$, which has only $25 \%$ of the initial Au. The reservoir for the lost gold is either the Pt metal of the capsule, the sulfide melt, or the $\mathrm{Pt}_{3} \mathrm{Fe}$ alloy present in GS-2 (discussed below).

Copper is transported into the silicate melt from the $\mathrm{CuS}$ source. Relative to the control experiment, GS-2 and GS-5 at $1400^{\circ} \mathrm{C}$ are enriched in $\mathrm{Cu}$ by approximately 4.5 times. There is little difference in the $\mathrm{Cu}$ enrichment between these experiments, even though GS-5 was of $1 \mathrm{~h}$ duration and contained no sulfide in contact with the silicate melt, and GS-2 was of $6 \mathrm{~h} \mathrm{du}-$ ration and contained both sulfide and metal in contact with the melt. At $1300^{\circ} \mathrm{C}$, GS-7 has a copper concentration six times that of the control experiment.

Nickel also is transported into the silicate melt in experiments with a sulfurous fluid. At $1400^{\circ} \mathrm{C}$, experiments GS-2 (6h) and GS-5 (1 h) contain approximately five times the nickel of the control experiment. At $1300^{\circ} \mathrm{C}$, experiment GS-7 has a Ni enrichment factor 


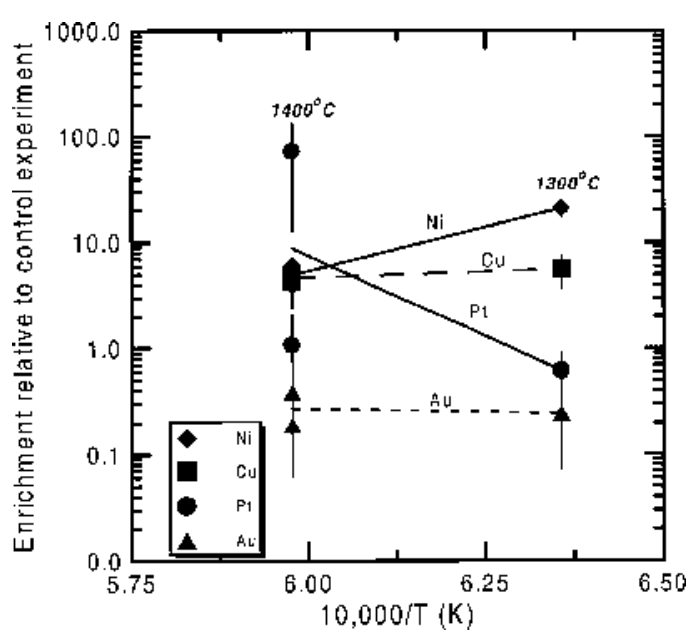

FIg. 4. Concentrations of $\mathrm{Au}, \mathrm{Cu}, \mathrm{Ni}$ and $\mathrm{Pt}$ in quenched silicate melt relative to those of control experiment GS-1. Error bars are one standard deviation about the mean based upon multiple analyses.

of 21. Thus the enrichment of nickel in the melt appears to have a strong negative correlation with temperature, whereas copper has a weak negative correlation. However, like copper, the degree of $\mathrm{Ni}$ enrichment seems to reach a steady-state value in experiments of only $1 \mathrm{~h}$ duration at $1400^{\circ} \mathrm{C}$.

$\mathrm{Pt}$ is enriched in the products of the sulfur-transfer experiments relative to GS-1. As expected from the presence of $\mathrm{Pt}_{3} \mathrm{Fe}$ alloy in GS-2 (Fig. 5), there is significant transport of $\mathrm{Pt}$ from the capsule into the silicate melt in experiments GS-5 and GS-2 at $1400^{\circ} \mathrm{C}$. These experimental products are enriched by factors of 1.1 and 72 times, with the 6-hour experiment, GS-2, being more enriched than the 1-hour experiment, GS-5. On the other hand, at $1300^{\circ} \mathrm{C}$ the melt only contains $61 \%$ of the concentration Pt measured in the control experiment, possibly due to heterogeneities in the starting rock powder.

Compositions of sulfides and metallic phases in contact with melt

Electron-microprobe data for selected quenched sulfide melts and metallic phases coexisting with the silicate melt at the center of the capsules are provided in Table 3. The compositions of quenched sulfide melts near the interface of the graphite and Pt capsules are not reported because they formed a disseminated intergrowth with graphite on a submicrometric to micrometric scale. This material was not successfully analyzed with the electron microprobe. Additional phases found near the graphite-Pt interface in GS-13 are $\mathrm{PtS}$ and $\mathrm{Pt}-\mathrm{Fe}$ alloy. In all of the experiments containing sulfide melts, the silicate melt has suffered significant loss of iron. Iron and sulfur dominate the sulfide melts. The quenched sulfide melts in GS-2 and -3 are finely intergrown with a Pt-Fe alloy (Fig. 5). Large blade-like masses of this alloy, up to $200 \times 50 \mu \mathrm{m}$ in cross-section, are present in GS-2, and its composition is $\mathrm{Pt}_{3} \mathrm{Fe}$. The $\mathrm{Pt}$ concentration in the sulfide found in GS-13 is $0.33 \mathrm{wt} . \%$, but varies widely, possibly reflecting the presence of $\mathrm{Pt}_{3} \mathrm{Fe}$ inclusions. The concentration of $\mathrm{Cu}$ in the sulfide formed in GS-13 is three times that of the sulfide in equilibrium experiment GS-17, but the nickel concentration in GS-13 sulfide is only $33 \%$ of that in GS-17 sulfide. The concentration of oxygen in the sulfides where it was measured is $1 \mathrm{wt} . \%$ or less, and highly variable, possibly owing to the presence of submicrometric inclusions of alloy in the sulfides.

\section{DisCUSSION}

These experiments demonstrate the efficacy of a sulfurous fluid as a medium to ensure at least partial equilibrium between a sulfide phase, in this case a sul-

TABLE 3. COMPOSITIOWS OF SULFLDES ANO METALS EN CONIACI WITH SILJCATE MELTS

\begin{tabular}{|c|c|c|c|c|c|c|c|}
\hline $\begin{array}{l}\text { Rug } \\
\text { Pltage }\end{array}$ & $\begin{array}{l}\text { GS-3 } \\
\text { sulfide } \\
+P t\end{array}$ & $\begin{array}{l}\text { GS-3 } \\
\text { alloy' }\end{array}$ & $\begin{array}{c}\text { GS-2 } \\
\text { alloy } \\
\text { metallic blate }\end{array}$ & $\begin{array}{c}\text { GS-2 } \\
\text { fine-grained } \\
\text { sulfide - allow }\end{array}$ & $\begin{array}{l}\text { GS-13 } \\
\text { sulfidic }\end{array}$ & $\begin{array}{l}\mathrm{GS}-15 \\
\text { sulfide }\end{array}$ & $\begin{array}{l}\text { GS-17 } \\
\text { sulfide }\end{array}$ \\
\hline 11 Analyses & 4 & 4 & 5 & 2 & 9 & 5 & 5 \\
\hline Fe & $1.01(13)$ & $3.15(34)$ & $8.32(4)$ & $40.78(78)$ & $61,19(61)$ & $62.17(82)$ & $62.73(47)$ \\
\hline $\mathrm{Ou}$ & $0.08(6)$ & $0.06\{3\}$ & $0.02(1)$ & $0.51(5)$ & 0.4069 & $0.13(4)$ & 0.12 (4) \\
\hline $\mathbf{S}$ & $8.93(18)$ & $0.39(78)$ & B. ${ }^{*}$ & $33.46 .(12)$ & $34,26(91)$ & $34.79(170)$ & $36.51(7)$ \\
\hline $\mathrm{Ni}$ & 0.08 (3) & $0.07(5)$ & B.D & 0.8769 & $0.70(10)$ & $0.95(6)$ & $1.06(5)$ \\
\hline Pt & $88.55(\mathrm{~T} 2)$ & $94.81(86)$ & $91.19(58)$ & $24.40(3.32)$ & $(5,3,3(57)$ & B.D. & B. D. \\
\hline 0 & & & & & $0.48(79)$ & $1.06(150)$ & BD. \\
\hline Total & 98,65 & 98.48 & 99.53 & 99.62 & 96.95 & 99.10 & 100.42 \\
\hline
\end{tabular}

* Below detection limit by electron mícieprobe. 


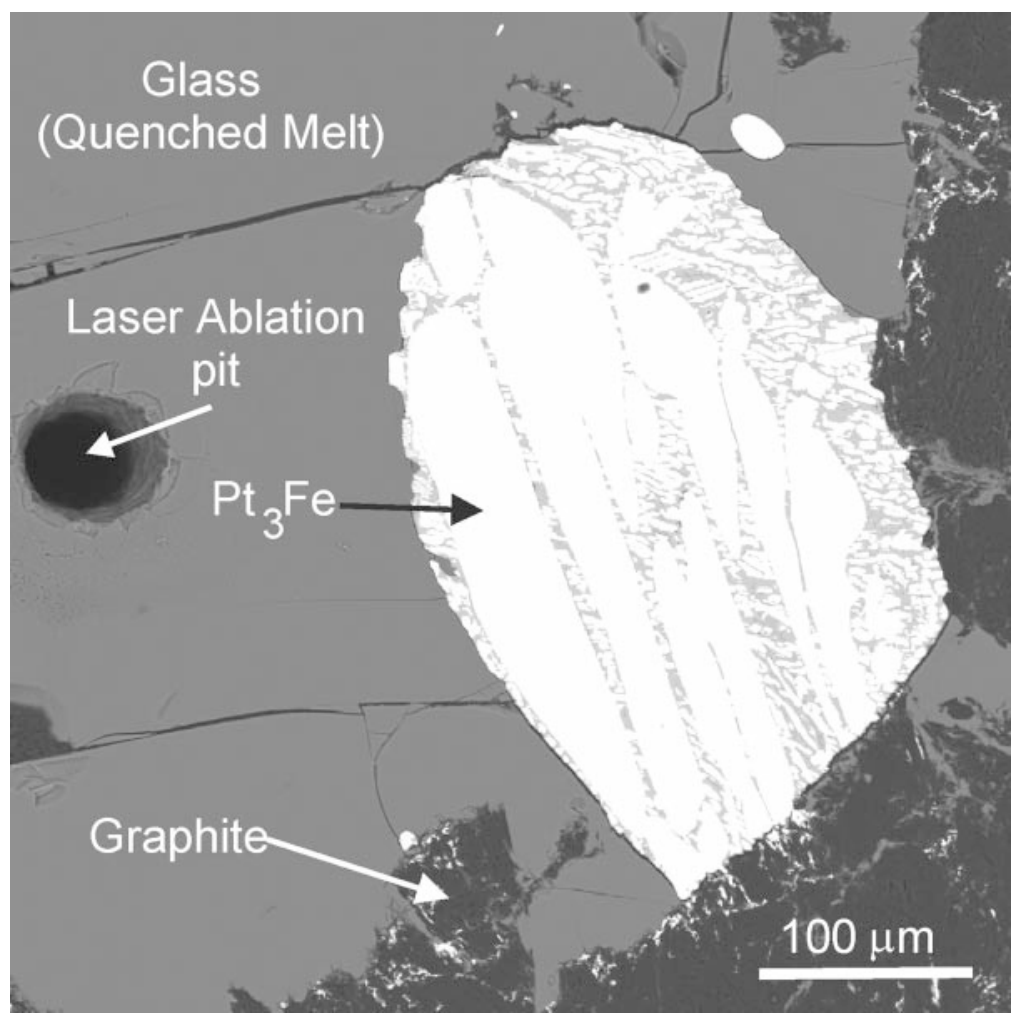

FIG. 5. Back-scattered electron image of quenched sulfide melt intergrown with $\mathrm{Pt}_{3} \mathrm{Fe}$ alloy in experiment GS-2. The quenched basaltic melt is light grey, the graphite capsule is black, the quenched sulfide melt is dary grey, and the white blades are the alloy. The hole near the left center at the end of the arrow is a laser-ablation pit.

fide melt, and a silicate melt. The sulfur concentrations in compositionally similar silicate melts in direct physical contact with sulfide melts and those separated from the sulfide melts by a graphite barrier are within experimental error. Thus, as the zeroth law of thermodynamics requires (Denbigh 1971), even though the sulfide melt at the base of the capsule was not in direct physical contact with the basaltic melt, sulfide saturation was achieved. Remarkably, the equilibrium concentration of $\mathrm{S}$ in the basaltic melt is achieved in less than 1 hour, indicative of the rapid transport of $\mathrm{S}$ in both the fluid and silicate melt phases.

The results also demonstrate that significant amounts of metals can be transported via the fluid phase, although we have not been able to ascertain if the distribution of trace elements reaches equilibrium in the sulfide and silicate melts. LAM-ICP-MS analyses demonstrate transport of $\mathrm{Ni}, \mathrm{Cu}$ and $\mathrm{Pt}$ into the melt and $\mathrm{Au}$ out of the melt. Nickel and copper concentrations in the melt also achieve steady-state values at $1400^{\circ} \mathrm{C}$ in approximately one hour, which demonstrates the rapidity of their transport in the fluid phase of these experiments.
Although the source of the troubling discrepancies between bulk-rock composition and results of laser-ablation analyses remains unknown and under investigation, we can combine the enrichment factors based upon LAM-ICP-MS analyses with the original bulk-rock concentrations of copper and nickel (Table 1) to provide preliminary estimates of the amount of $\mathrm{Cu}$ and $\mathrm{Ni}$ transported into the melt by the sulfurous fluid. At $1400^{\circ} \mathrm{C}$, the amounts of $\mathrm{Cu}$ and $\mathrm{Ni}$ transported are $8 \times$ $10^{-7} \mathrm{~g}$ and $3 \times 10^{-6} \mathrm{~g}$, respectively. At $1300^{\circ} \mathrm{C}$, the amount of $\mathrm{Ni}$ transported is $1 \times 10^{-5} \mathrm{~g}$, and that of $\mathrm{Cu}$ is $1 \times 10^{-6} \mathrm{~g}$. The transport of $\mathrm{Cu}$ and $\mathrm{Pt}$ into the melt is supported not only by the LAM-ICP-MS analyses of quenched silicate melts, but also by the compositions of sulfide melt inside the silicate melt of S-transfer experiment GS-13; the silicate melt is enriched in $\mathrm{Cu}$ and $\mathrm{Pt}$ relative to the sulfide melt in equilibrium experiment GS-17 at the same temperature. The presence of $\mathrm{Pt}_{3} \mathrm{Fe}$ alloy, noted in GS-2, GS-3 and at the base of GS-13, has never before been observed in hundreds of equilibrium experiments on basaltic starting materials encased in graphite-Pt capsules performed by the senior author. 
Its presence must be due to the sulfurous fluid phase created in our experiments and its ability to transport Pt from the outer capsule into the melt, where it combines with $\mathrm{Fe}$ from the melt to form the alloy. The amount of Pt transported in GS-2 can be conservatively calculated by multiplying the volume of the largest crystal of $\mathrm{Pt}_{3} \mathrm{Fe}$, $200 \times 50 \mu \mathrm{m}$ in cross section by an assumed thickness of $50 \mu \mathrm{m}$, by its density, $18.45 \mathrm{~g} \mathrm{~cm}^{-3}$ (calculated from unit-cell data in Cabri \& Feather 1975), and its Pt concentration, $95 \mathrm{wt} . \%$, to yield a value of $8.8 \times 10^{-6} \mathrm{~g}$. Although iron must be transported in the fluid phase as the system strives to reach equilibrium, the fluid does not enrich the silicate melt in iron, but instead seems to deplete it, on the basis of the low $\mathrm{FeO}^{*}$ concentration of the melt in sulfide-free GS-7 (Table 2).

The potential significance of fluid-phase transport of ore metals has been previously recognized and studied experimentally by many researchers (see review by Candela \& Piccoli 1995). The studies most similar to ours are those of Fleet \& Wu $(1993,1995)$ and of Ballhaus et al. (1994). However, ours is the first study to demonstrate significant transport in a fluid phase dominated by sulfur at high pressure. In experiments performed in sealed silica tubes heated to $1000^{\circ} \mathrm{C}$ in a 1-atmosphere furnace, Fleet \& Wu (1993) found that fluids containing only sulfur did not significantly transport ore metals; they only found significant transport when chloride was added to the system. The difference in the results of this study and those of Fleet \& Wu $(1993,1995)$ are attributed to the presence of $\mathrm{H}_{2} \mathrm{~S}$ in the gas phase of this study, which was present in only small amounts, if at all, in the systems studied by Fleet \& Wu (1993, 1995). The experiments of Ballhaus et al. (1994) involved partitioning of metals into hydrous fluids at pressures between 0.4 and $1.0 \mathrm{GPa}$ and temperatures from 800 to $900^{\circ} \mathrm{C}$. Their study demonstrated that $\mathrm{Au}$, $\mathrm{Cu}, \mathrm{Fe}$, and $\mathrm{Pt}$ could be transported in a fluid, but they did not detect significant transport of Ni. Comparison of the results of these previous studies and this study demonstrate the significance of fluid composition on the solubility of ore metals in the fluid and their transport at high temperatures and pressures. Clearly, many more studies are required to quantitatively understand the effects of fluid composition on metal transport in hightemperature, high-pressure fluids.

\section{GEOLOGICAL IMPLICATIONS}

The experimental results of this study strongly support the fluid-transport mechanism of sulfur and metal from country rocks into mafic magmas. Not only is sulfur transported, but also significant quantities of base metals $\mathrm{Cu}$ and $\mathrm{Ni}$ and the precious metal $\mathrm{Pt}$, and possibly $\mathrm{Au}$. The bulk assimilation of country rocks therefore may not be necessary for sulfur to be incorporated into the magmas, or it may operate in conjunction with the fluid-transport mechanism. The experimental evi- dence suggests that more $\mathrm{Cu}$ and $\mathrm{Ni}$ are transported at lower temperatures, which might make the fluid-transport process even more efficient at more realistic magmatic temperatures than those of this study. The rapidity of the fluid-transport mechanism in the experiments bodes well for its operation in the natural setting. However, a caveat must be added, that the time necessary for transport of a sulfurous fluid through a few $\mathrm{mm}$ of a graphite capsule will be orders of magnitude different from the natural process, where fluids must travel through a network of cracks over a much longer distance. Additional unknowns affecting the efficacy of the process in nature involve the rate of sulfidation reactions of mafic minerals, which will remove sulfur from the fluid phase, the effects of differing oxygen fugacities, and how addition of other volatile species to the fluid will affect metal solubilities.

In theory, it is possible to discern between the assimilation and fluid-transport mechanisms in natural rocks. Although both mechanisms will produce crustal $\delta^{34} \mathrm{~S}$ signatures, the assimilation mechanism should produce a correlation between sulfur isotopic signatures and the signatures of other isotopic systems, which is not expected for the fluid-transport mechanism. Bulk assimilation of country rocks should increase alkali concentrations in the magma because of their ease of contamination relative to non-alkalis (Watson 1994). Therefore, assimilation should result in a correlation between $\mathrm{S}$ and alkali concentrations, whereas the fluidtransport mechanism is not expected to produce such a correlation. Additional evidence of the operation of the fluid-transport mechanism should be the presence of a sulfur-depleted, but not partially melted, halo around an intrusive body.

\section{Conclusions}

This study has demonstrated that both sulfur and metals can be transported via a fluid phase from a sulfide melt into a basaltic melt in a short time. Sulfur equilibrium between basaltic and sulfide melts separated by a gas-permeable graphite membrane appears to be established in under one hour at the high-temperature conditions studied. These results support models of fluid-transport enrichment of basaltic magmas by $\mathrm{S}$ extracted from the country rocks and indicate that metals may also be transferred from the country rocks into the magmas, eventually to form ore deposits. Such fluidtransport enrichment may be the sole mechanism operating or may aid wholesale assimilation in the enrichment of magmas in sulfur and ore metals.

\section{ACKNOWLEDGEMENTS}

This work constitutes the B.Sc. research of G. Simon. Reviews of this paper by Mike Fleet, C. Freda and an anonymous reviewer were greatly appreciated. 
Funding for this project was provided by FCAR Equipe Grant 99-ER-3065, and NSERC grants OGP89662 and CPG0183275.

\section{REFERENCES}

Ballhaus, C., Ryan, C.G., Mernagh, T.P. \& Green, D.H. (1994): The partitioning of $\mathrm{Fe}, \mathrm{Ni}, \mathrm{Cu}, \mathrm{Pt}$, and $\mathrm{Au}$ between sulfide, metal, and fluid phases. Geochim. Cosmochim. Acta 58, 811-826.

Barnes, S.-J., Zientek, M.L. \& Seversen, M.J. (1997): Ni, $\mathrm{Cu}, \mathrm{Au}$ and platinum-group element contents of sulphides associated with intraplate magmatism. Can. J. Earth Sci. 34, 337-351.

BoHLEN, S.R. (1984): Equilibria for precise pressure calibration and a frictionless furnace assembly for the piston-cylinder apparatus. Neues Jahrb. Mineral., Monatsh., 404412 .

CABRI, L.J. \& FeAther, C.E. (1975): Platinum-iron alloys: a nomenclature based on a study of natural and synthetic alloys. Can. Mineral. 13, 117-126.

Candela, P.A. \& Piccoli, P.M. (1995): Model ore-metal partitioning from melts into vapor and vapor/brine mixtures. In Magmas, Fluids, and Ore Deposits (J.F.H. Thompson, ed.). Mineral. Assoc. Can., Short-Course Handbook 23, 101-127.

CARroll, M.R. \& Webster, J.D. (1994): Solubilities of sulfur, noble gases, nitrogen, chlorine, and fluorine in magmas. In Volatiles in Magmas (M.R. Carroll \& J.R. Holloway, eds.). Rev. Mineral. 30, 231-279.

Clemens, J.D. \& Mawer, C.K. (1992): Granitic magma transport by fracture propagation. Tectonophys. 204, 339-360.

DALPÉ, C. \& BAKER, D.R. (2000): Experimental investigation of LILE, HFSE, and REE partitioning between calcic amphibole and basaltic melt: the effects of pressure and oxygen fugacity. Contrib. Mineral. Petrol. 140, 233-250.

\& SuTTON, S.R. (1995): Synchrotron Xray-fluorescence and laser-ablation ICP-MS microprobes useful instruments for analysis of experimental run-products. Can. Mineral. 33, 481-498.

DenBigh, K. (1971): The Principles of Chemical Equilibrium. Cambridge University Press, Cambridge, U.K.

FERRY, J.M. (1991): Dehydration and decarbonation reactions as a record of fluid infiltration. In Contact Metamorphism (D.M. Kerrick, ed.). Rev. Mineral. 26, 351-393.

\& BAUMGARTNER, L. (1987): Thermodynamic models of molecular fluids at the elevated pressures and temperatures of crustal metamorphism. In Thermodynamic
Modelling of Geological Materials (I.S.E. Carmichael \& H.P. Eugster, eds.). Rev. Mineral. 17, 323-365.

Fleet, M.E. \& WU, TsaI-WAY (1993): Volatile transport of platinum-group elements in sulfide-chloride assemblages at $1000^{\circ} \mathrm{C}$. Geochim. Cosmochim. Acta 57, 3519-3531.

\& (1995): Volatile transport of precious metals at $1000^{\circ} \mathrm{C}$ : speciation, fractionation, and effect of base-metal sulfide. Geochim. Cosmochim. Acta 59, 487495.

Holloway, J.R. \& BlanK, J.G. (1994): Application of experimental results to $\mathrm{C}-\mathrm{O}-\mathrm{H}$ species in natural melts. In Volatiles in Magmas (M.R. Carroll \& J.R. Holloway, eds.). Rev. Mineral. 30, 187-230.

Hoosain, L. (1999): Solubility of Gold in Granitic Melts and Partitioning of $\mathrm{Au}$ Between Melt and $\mathrm{NaCl}$-Saturated Fluid or Sulfides. M.Sc. thesis, McGill Univ., Montreal, Quebec.

Lesher, C.M. \& CAmpBell, I.H. (1993): Geochemical and fluid dynamic modelling of compositional variations in the Archean komatiite-hosted nickel sulfide ores in Western Australia. Econ. Geol. 88, 804-816.

MAHOOD, G.A. \& BAKER, D.R. (1987): Experimental constraints on depths of fractionation of mildly alkalic basalts and associated felsic rocks: Pantelleria, Strait of Sicily. Contrib. Mineral. Petrol. 93, 251-264.

RIPLEY, E.M. (1999): Systematics of sulphur and oxygen isotopes in mafic igneous rocks and related $\mathrm{Cu}-\mathrm{Ni}-\mathrm{PGE}$ mineralization. In Dynamic Processes in Magmatic Ore Deposits and their Application in Mineral Exploration (R.R. Keays, C.M. Lesher, P.C, Lightfoot \& C.E.G. Farrow, eds.). Geol. Assoc. Canada, Short Course 13, 133-158.

Robie, R.A., Hemingway, B.S. \& Fisher, J.R. (1979): Thermodynamic properties of minerals and related substances at $298.15 \mathrm{~K}$ and $1 \mathrm{bar}\left(10^{5}\right.$ Pascals) pressure and at higher temperatures. U.S. Geol. Surv., Bull. 1452.

Thériault, R.D., BARnes, S.-J. \& SEVERson, M.J. (1997): The influence of country-rock assimilation and silicate to sulfide ratios ( $\mathrm{R}$ factor) on the genesis of the Dunka Road $\mathrm{Cu}-\mathrm{Ni}$ - platinum-group element deposit, Duluth Complex, Minnesota. Can. J. Earth. Sci. 34, 375-389.

WATSON, E.B. (1994): Diffusion in volatile-bearing magmas. In Volatiles in Magmas (M.R. Carroll \& J.R. Holloway, ed.). Rev. Mineral. 30, 371-411.

WENDLANDT, R.F. (1982): Sulfide saturation of basalt and andesite melts at high pressures and temperatures. Am. Mineral. 67, 877-855.

Received October 20, 1999, revised manuscript accepted October 3, 2000. 